\title{
Indigenous Land Grabbing and Forests Right Defilement by Small Farm Holders in Nguti, Cameroon
}

\author{
Tende Renz Tichafogwe, Ndjounguep Juscar \\ Department of Geography, the University of Yaounde 1, Yaounde, Cameroon \\ Email: renztende@yahoo.com, ndjounguep@gmail.com
}

How to cite this paper: Tichafogwe, T. R., \& Juscar, N. (2020). Indigenous Land Grabbing and Forests Right Defilement by Small Farm Holders in Nguti, Cameroon. Current Urban Studies, 8, 129-139. https://doi.org/10.4236/cus.2020.81006

Received: February 23, 2020

Accepted: March 28, 2020

Published: March 31, 2020

Copyright $\odot 2020$ by author(s) and Scientific Research Publishing Inc. This work is licensed under the Creative Commons Attribution International License (CC BY 4.0).

http://creativecommons.org/licenses/by/4.0/ (c) (i) Open Access

\begin{abstract}
Land grabbing from small farm holders of Nguti is the major cause of environmental degradation and forest right violation. This article posits how the rural communities of Nguti are experiencing a range of political skirmishes resulting from large scale land acquisition which is threatening local land-use practices and access to land. The paper divulges that oil palm enterprises have encouraged the proliferation of small grab farm holders. This has forced members to engage in illegal sale of large portions of forest land leading to environmental degradation and distortion in their livelihood activities. A three-component integration method of questionnaire administration, GPS recordings and interview/ field observation were used for data collection. The data was analysed using the Microsoft excel spread sheet and the maps realized through the QGIS software. Results from findings adhere to the fact that $61 \%$ of land acquisition by the minor farm holders comes from local chiefs, $26 \%$ bought land from the indigenes while $13 \%$ obtained it from elites and family. Land conflicts occur between the small farm holders and the local community because they have intruded in land without authorisation from the traditional council leading to boundary conflicts. Some $10 \%$ of the small farm holders have acquired land influentially as a violation of the indigenous land rights. The activity has caused environmental squalor in the form of habitat loss as forests and plants are at risk of extinction. There is water resource depletion as the streams used by the villagers for portable water have completely withered. Inappropriate water management, fertilizers and pesticides run-off from fields to adjacent rivers and lakes and contaminate groundwater sources. This article acclaims that there is a need to sensitise the communities, especially the youths, on illicit land sales and incessant monitoring of the Nguti area against environmental degradation.
\end{abstract}




\section{Keywords}

Land Grabbing, Small Farm Holders, Right Violation, Environmental Degradation, Nguti

\section{Introduction}

Large-scale land acquisition by foreign interests is a major driver of agrarian change in the productive regions of Africa as well as a threat to environmental degradation (United Nations, 2013). In recent years, a global land rush has resulted in a massive rise in the number of people in sub-Saharan African countries being evicted from or denied access to their own land. This is done sometimes in violent confrontation with the authorities as big business moves in. Offered little by way of compensation or alternative livelihoods, many people are forced into increased poverty, hunger and dispossession (Julian, 2014). This threat comes from foreign and local investors who perpetrate land grabbing, leading to land tenure conflicts which are recurrent in Africa in general and Cameroon in particular. Foreign investors come with huge promises to the local authorities who, without any consultation, release their land at the detriment of the local population (Tinyade, 2012).

Rural communities across Cameroon in general and the South West Region in particular are experiencing severe land grabbing from small farm holders (Ngwa, 1997). This form of land deals, which is not based on free and prior informed consent of the Nguti land users, is accompanied by disregard of social economic and environmental impact (Friis Cecilie and Reenberg Annette, 2010). This however provokes resistance since access to land is not only a matter of wealth, but of survival, identity and belonging (Aarts, 2009). The Nguti Subdivision is experiencing a range of political conflicts resulting from Large-scale land acquisition, in which commercial interests are threatening local land-use practices and access to land. This has made the local population lose even farm land used for subsistence agriculture which has therefore increased the level of poverty in such areas (Nguti Council, 2016). Some villages in Nguti subdivision have been earmarked for the development of oil palm plantations. The growth of oil palm enterprises has triggered the proliferation of small farm holders that supply palmoil to large industrial palm plantations within the Nguti area (Nguti Council, 2008).

This land grabbing from small palm farm holders has encouraged the Nguti local community to engage in a thoughtless sale of a large portion of forest land to the palm farm holders. The palm holders clear large portions of the forest indiscriminately, causing a lot of environmental degradation thereby threatening the livelihood sources of these forest communities. Furthermore, proactive forest community member's rights and voices are silent and can no longer complain because they have collected money from the farm holders (Nguti Council, 2008). 
The fear is that if such a practice is not checked, land conflict in Nguti will increase and cause severe disputes, if not inter tribal wars. The ownership of indigenous land by palm holders will in the long run damage the Nguti environment.

Nguti Sub-division is part of the larger Kupe-Manengouba Division in the Southwest Region of Cameroon. It is located on latitude $5^{\circ} 90^{\prime}$ and $5^{\circ} 25^{\prime}$ North and longitude $9^{\circ} 12^{\prime}$ and $9^{\circ} 28^{\prime}$ East along the Kumba-Mamfe Highway (Figure $1)$.

It provides access to neighbouring Nigeria's tropical forests which are extensive and rich in biodiversity. The forests are protected areas and have reserves of high conservation value. They include the Banyang-Mbo Wildlife Sanctuary which covers 69,147 hectares of surface area, the proposed Nguti Council Forest with 11,919 ha and part of the Bakossi National Park with 29,320 ha that occupies much portion of land in this Subdivision, with farming being the dominant local activity. This article therefore seeks to address the indiscriminate sale of land by forest communities to small farm holders which does not only violate forest community rights, but also promotes environmental degradation.

\section{Methodology}

A participatory approach method of data collection involving some community members and the facilitators was used. This was done through a three-component integration method of questionnaire administration, GPS recordings, interviews as well as field observation. Data collection was done for twenty one days from the 19th of January to the 8th of February 2018. A total of eleven villages (Ayong, Babensi II, Ebanga, Ediengoh, Ofrikpabi, New Konye, Nguti, Nkwenfor, Ekenge, Osirayib and Sikam) from four clans (Bebum, Bassossi, Ngemengoe and Upper Balong) of the Nguti sub division were sampled. Also, 89 questionnaires were administered to have the respondent's perception on land grabbing in their area.

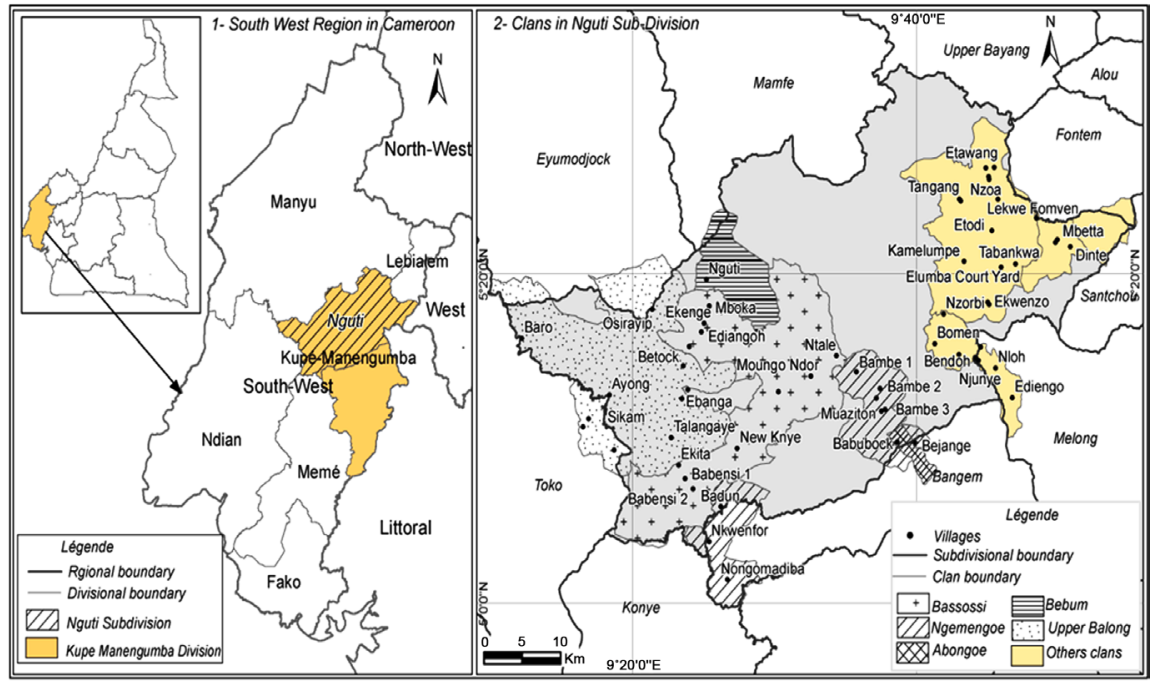

Figure 1. Location of the zone of study. Source: NIC in 2014 and Field work in 2018. 
The questionnaire was aimed at raising awareness to the local population on the right to own land and dangers involved in selling it. The focus was to acquire information on the mode of operation used by the grabbers to acquire land. This information falls in line with the objective of the paper which was to show that indiscriminate sale of land violates forest rights and damages the environment. The clans were chosen because they are hot spots for many agro and semi-agro industrial establishments, coupled with the level nature of the terrain which is suitable for export crop cultivation. One village was sampled in the Bebum clan, five in Bassossi, one in Ngemengoe and four villages in the Upper Balong clan. The villages in each of these clans were selected based on road accessibility and security since the area is generally inaccessible.

The Geographical Positioning System was used to collect the geographic coordinates and position of each farm owned by the Semi Palm holders of each plantation and it was recorded for map production. The questionnaire was administered to also sample the population's perception on the effects of forests right violation and environmental degradation from small farm holders. Information obtained in the questionnaires concerned the size of the plantation, the types of crops cultivated and techniques used in cultivation. Some also concerned how the land was acquired and its effects on the local population. Interviews and field observation were conducted on some affected members of these communities in order to get first-hand information on how they are being affected by the impact of land grabbing and environmental degradation. All data collected was analysed using the Microsoft Excel spread sheet and the maps realized through the QGIS software to generate results.

\section{Results Analyses and Discussion}

Results from findings propound that the indiscriminate sale of land has provoked the violation of forest community rights and led to environmental degradation. The indiscriminate sales which have been triggered by land grabbers affect subsistence farmers, pastoral societies, forest dwellers as well as fisher men who depend on land and natural resources for their livelihood (United Nations, 2010).

\subsection{The Impact of Indiscriminate Sales of Land to Small Farm Palm Grabs Holders}

The indiscriminate sale of land to grabbers constitutes a major problem to land governance in Cameroon. These land deals promote drastic changes and risks on the communities as their access to land is denied, food security becomes threatened and the environment is pruned to hazards (Schoneveld, 2013). In the Nguti area, some four sources of land acquisition by small palm holders were identified. Results from field work revealed that $61 \%$ of the land own by palm holders is bought from the local chiefs and traditional councils. Furthermore, $26 \%$ was bought from the local indigenes and 13\% from other sources such as elites and 
family. This land acquisition which breeds much discord and tension could possibly lead to conflicts or even inter-tribal wars, if not checked. Some 89 small palm holders were identified in the four sampled clans of Nguti (Table 1).

Table 1 shows that the Upper Balong clan has the highest number of small farm holders with a $38.20 \%$ ranking amongst the four. This is due to the influence of the sustainable oil plantations which provides a ready market for the palms from the small holders. Also, the flat and gentle nature of terrain is suitable for export crop cultivation. The area is easily accessible as it is closer to the Kumba-Mamfe highway. The Ngemengoe clan, on the contrary, has the least number of small palm holders with a percentage of 6.74 . This is due to its poor accessibility and closeness to the hinterland.

The small holder farmers are involved in the cultivation of several export crops (Figure 2).

Crops such as rubber, palms and cocoa as well as food crops such as plantains and cocoyam are cultivated by small farm holders. Field observations revealed that a significant number of smallholders cultivate cocoa which occupies about 386 hectares on 58 different portions of land. There is the proliferation of palm plantations with a total of 340 hectares on 25 different portions of land. This can be explained by the fact that more than $75 \%$ of the area produces palms to sell to

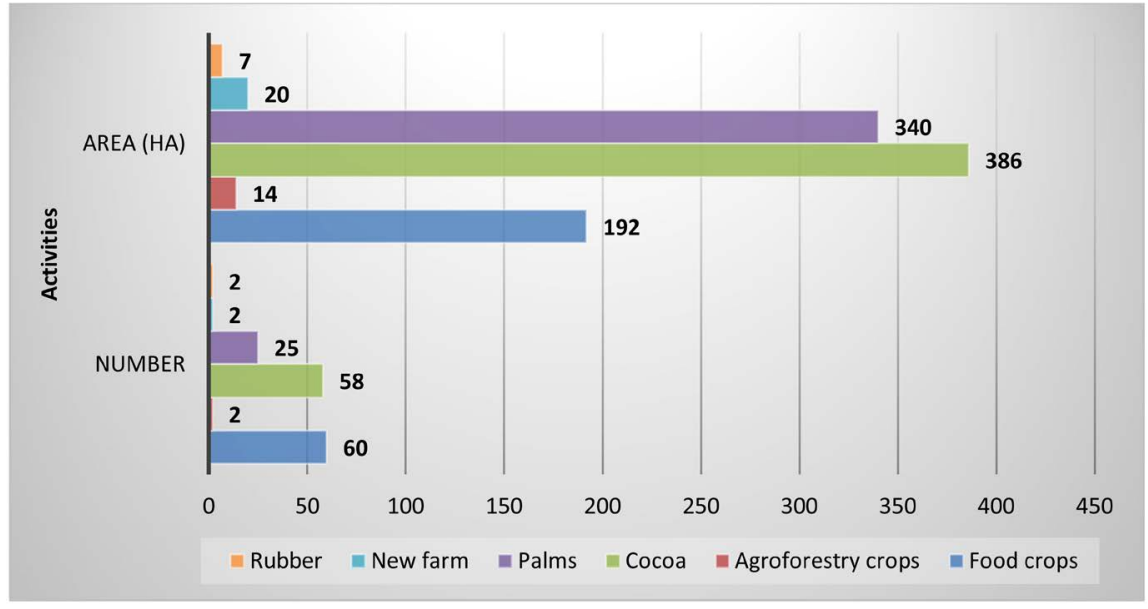

Figure 2. Small holder crop type cultivation in Nguti. Source: Field work in 2018.

Table 1. Number of small farm palm holders per clan in Nguti.

\begin{tabular}{ccc}
\hline Clan & Number Sampled & Percentage \\
\hline Upper Balong & 34 & 38.20 \\
Bassosi & 31 & 34.84 \\
Bebum & 18 & 20.22 \\
Ngemengoe & 6 & 6.74 \\
Total & 89 & 100 \\
\hline
\end{tabular}

Source: Field work in 2018. 
the oil plantations implanted in the Nguti area. Rubber, on the contrary, represents the least cultivated crop in this area, occupying 7 hectares with 2 portions of land. In-depth field works enabled this paper to observe how small holders do practice agro forestry which occupies about 20 hectares and are involved in the planting of trees such as Irvingiaga bonensis (bush mango) which is a very important climate change mitigation crop. There is also the creation of new farms which have not yet been put into use, occupying 20 hectares of land. Crop cultivation by small farm holders has existed in Nguti for the past four decades. The crop types vary with respect to the periods and the hectares of land used as seen in Table 2.

The variation in the crop type and the portion of land used depends on the number of small farm holders that had access to land during such periods. The crop types moved from two in 1976 to four in 1990 because many grabbers became interested in the Nguti land as the Palm oil Company was created in the area. Table 2 reveals 2016 as the peak of crop cultivation. This is because the Kumba-Mamfe road was fully operational which eased access to and from the farms. Crops could therefore be transported to the markets and more grabbers were interested in the area. There is however a drop in the activity from 2016 to 2018 due to the crisis in the region. The small holders have however occupied much land in the Nguti area (Figure 3).

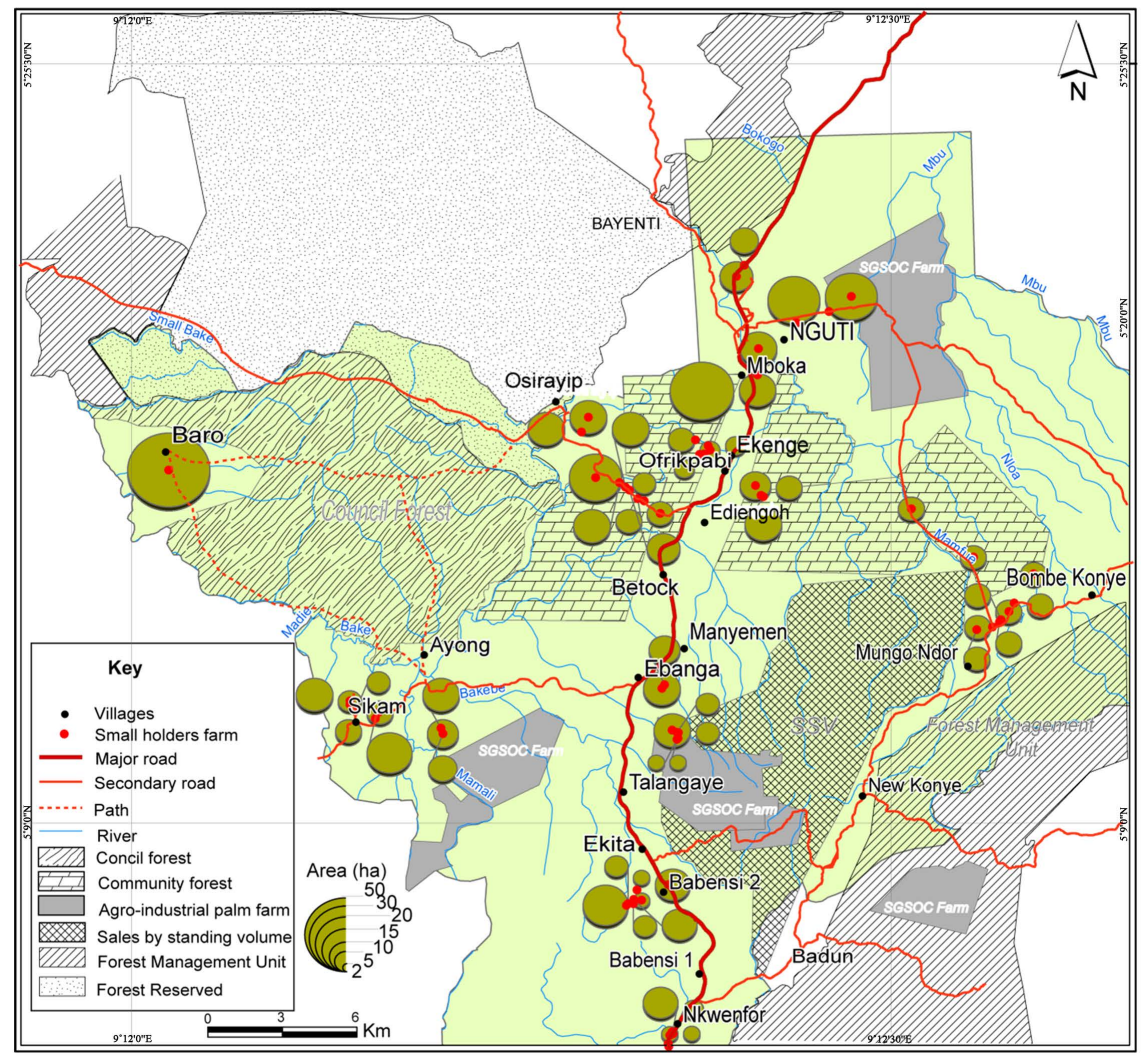

Figure 3. Spatial representation of the small holder plantations in Nguti. Source: NIC in 2014 and Field work in 2018. 
Table 2. Small farm holders crop cultivation in Nguti from 1976 to 2018.

\begin{tabular}{|c|c|c|}
\hline Period & Area (ha) & Crop Type \\
\hline 1976 & 11 & Cocoa, palm \\
\hline 1988 & 9 & Cocoa \\
\hline 1990 & 24 & Cocoa, plantain, palm, food crops \\
\hline 1993 & 4 & Cocoa \\
\hline 1997 & 3 & Cocoa, palm \\
\hline 2000 & 16 & Cocoa, palm, food crops \\
\hline 2001 & 26 & Cocoa, palm, food crops \\
\hline 2002 & 10 & Cocoa, plantain \\
\hline 2005 & 25 & Cocoa, plantain, palm \\
\hline 2007 & 10 & Cocoa \\
\hline 2008 & 4 & Cocoa, plantain \\
\hline 2010 & 24 & Cocoa, palm \\
\hline 2011 & 17 & Palm, cocoa \\
\hline 2014 & 8 & Cocoa, plantain, palm \\
\hline 2015 & 11 & Cocoa, palm \\
\hline 2016 & 80 & Food crops, palm, plantain, cocoa \\
\hline 2017 & 77 & Cocoa, plantain, palm \\
\hline 2018 & 21 & Palm, cocoa, plantain \\
\hline
\end{tabular}

Source: Nguti Council in 2010 and Field work in2018.

Figure 3 shows the occupation of the Nguti land by small holders which has even encroached into government reserves and concessions in Osirayib, Nkwende hills, Ofripabi, Ekenge as well as the Mbacof community forest. Most of the small holders are located around the Kumba-Mamfe roads, since it is easier for them to transport their produce to the market. It is interesting to note that the small palm holders are looking for possibilities to expand their farm sizes since business is lucrative. This will mean that the phenomenon of land grabbing will increase since the opportunities of making more money are available (Von Brawn \& Meinzen Dick, 2009).

The small farm holders in Nguti are interested in the area due to the ready market of their products. Those involved in food crops sell their products mostly in the village areas, while those for export crops sell out of the Nguti area, that is, to Kumba and beyond. Most of the small holders are regular suppliers to the Sustainable oil company in the Upper Balong Clan and the Telcar Cocoa Company. This ready market explains why the phenomenon of land grabbing for small farm holders is on a rise in this area. Field reports show that there is a conflict between the local population and the small farm grab holders. The conflicts arise because the grabbers have either refused to pay the demanded amount of 
money requested by the community, or have refused to settle in the community. Others have intruded into the land without an authorisation from the owners and traditional councils. The grabbers have therefore trampled on the rights of the local farmers, thus causing them to become beggars in their own homeland (International Labour Organisation, 2009). These land grabbers do so with their intension of making money from their products and since they do not reside in the farm areas, are not environmentally friendly (Smaller \& Mann, 2009).

\subsection{The Effects of Small Farm Holder Grabbing on the Nguti Environment}

One of the major drawbacks to land grabbing in Africa is the negative effect it has on the environment (IIED, 2009). Results from findings show that the activities of the small farm holders have caused some environmental degradation to the Nguti environment through the loss of habitats, water resource depletion as well as pollution (Martin, 2007).

The grabbing of land from small farm holders has enabled large amounts of forest to be destroyed in the Nguti area (Plate 1).

Plate 1 shows the burning of forest in Sikam (a) and the cutting down of trees in Ediangoh (b) villages by grabbers for palm and other crop cultivation. In the course of creating their farms, the grabbers cut and burn down trees. Useful plants such as Bush Mango used for traditional treatment are threatened by extinction due to such practices. This illicit forest exploitation will lead to forest destruction, if it is not controlled.

The proliferation of small farm holders in Nguti has caused a lot of water crisis in the area. Streams used by the local community as a source of portable drinking water are drying-up. The people walk for long distances in search of portable water and, at times, are forced to drink from untreated sources as in the Ayong village (Plate 2).

Plate 2 exhibits village portable water drying-up in Ayong (C) and the Upper Balong clan (D) in the Nguti area. The resulting effect of this dryness is the consumption of water by the villagers from the Mamere village noted for its high

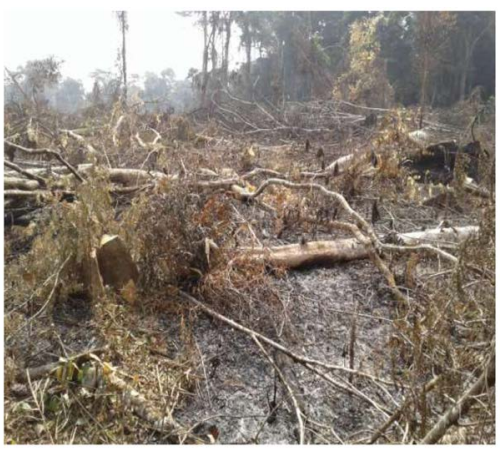

(a)

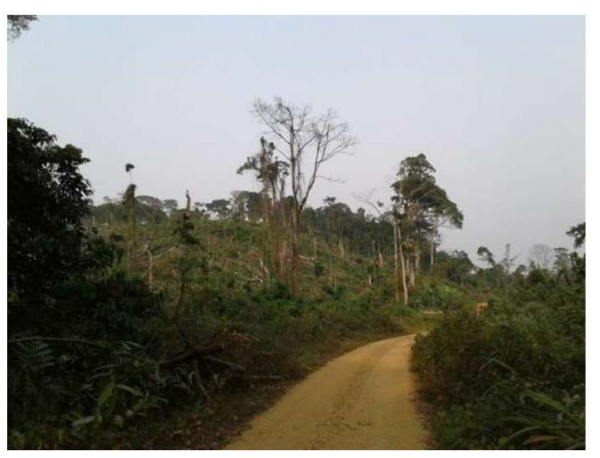

(b)

Plate 1. Forest destruction in the Nguti area from small farm holders. Photos by Ndjounguep in 2018. 

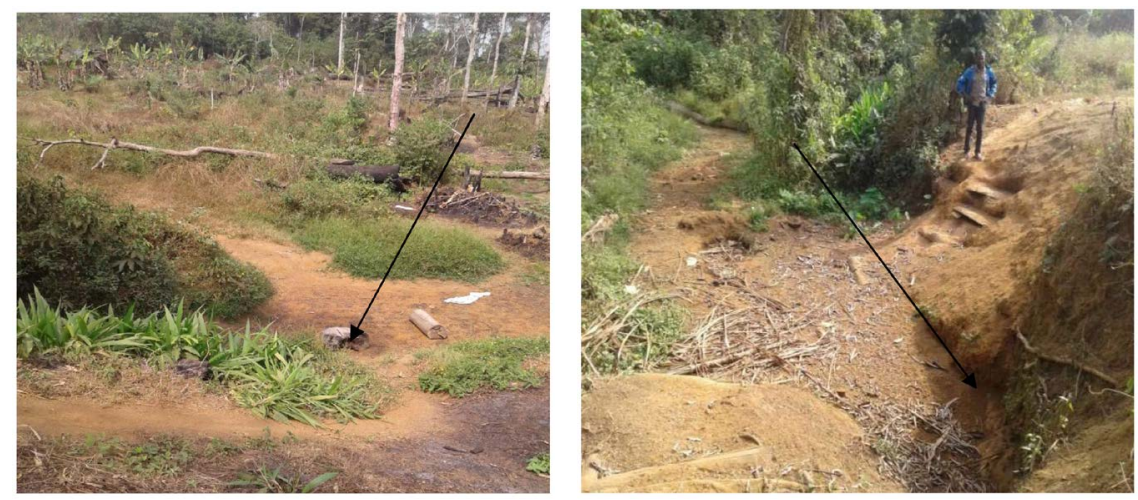

Plate 2. Stream water drying-up in the Nguti area. Photos by Ndjounguep in 2018.

rate of pollution [8]. This illicit consumption of untreated portable water has triggered the effects of water born diseases such as cholera as well as diarrhoea in the Nguti area. Further water pollution from land grabbers comes from the pesticides, fertilizers and other agrochemicals used by the small farm holders. Pesticide spraying leads to the pollution of adjacent land, rivers or wetlands. The pesticides and fertilizers from poor water management and irrigation technology commonly run-off from fields to adjacent rivers and lakes and contaminate groundwater sources. These effects, among others, enabled this study to conclude that land grabbing from small farm holders has negatively affected the Nguti environment.

\section{Conclusion and Recommendation}

Allowing land to become a vehicle for wealthy corporations and individuals to become richer while pushing vulnerable rural people into poverty and hunger is unjust, unwise and unethical (Julian, 2014). Such is the case with the Nguti area from small farm land grabbers. This paper found out that land grabbing in Nguti was instigated by agro-industrial establishments and the construction of the Kumba-Mamfe that facilitated movements. The effect of small farm holder grabbing in Nguti has led to gross restriction on land ownership by the local population, increased conflict and environmental degradation. What is observed is that, there are poor education and information on land laws by the local population. As such, the grabbers take advantage of this limitation and exploit the land owners who are poor and unable to sustain a living with their little income. Consequently, illicit land sales, especially by the youths, have become the order of the day in Nguti since no organised structures exist in the management and monitoring of land sales. Land conflict between the grabbers and the local population, and even with neighbouring villages, is becoming rampant as traditional local authorities are settling land disputes and tensions from the grabbers and the local population. This is because there are no land use maps and plans which could adequately be used to halt the arguments on boundary limits. The fear is that if these conflicts are not checked, they might degenerate into intertribal wars. The small farm holders have not only created land conflicts but have 
as well caused environmental problems to the Nguti area. Trees and other farmlands have been burnt down, stream water sources for home consumption dried-up and water pollution from pesticide and other agro-chemicals application noticed. These environmental effects unfortunately have occurred uncontrolled and affected Nguti. This paper however focused on the hotspots of Nguti which were earmarked for the development of oil palm plantations. Therefore, other areas without these plantations might experience grabbing in a different manner from that of this article. Furthermore, information concerning land might have been withheld ignorantly or deliberately. Nevertheless, this did not in any way reduce the chances of this article to arrive at concrete results.

This paper strongly advocates that incessant sensitisation of the Nguti population, especially the youths on illicit land sales and the importance of ownership be done. This can be done through structures such as the traditional council which will carry out awareness discussions on yearly basis with the population especially the youths. Furthermore, State organs and authorities such as the local council and Divisional Officers should be used to monitor, reduce or curb land grabbing through field control of land and ownership rights facilitation. In this way, all land owned will be registered and sales monitored to avoid grabbing. Besides, local development structures such as farmers' cooperatives should be created to reduce unemployment and encourage the local population to farm and sell their products to large markets as well. The local farmers will be motivated by the available market of their products and the income generated from the activity. This will increase their income and reduce poverty in the area. The local population will improve on their livelihood and avoid selling their land indiscriminately. More so, land conflicts and disputes will be avoided if the local population is well schooled on land law. This will be further strengthened by the production and strict use of the land use plans and land use maps of the Nguti area. As such, the violation of land rights and conflicts will be avoided, or strictly monitored, to reduce or curb conflicts. Forest rights defilement and environmental degradation in Nguti is as a result of anarchy perpetrated by land grabbers from the indiscriminate sales. The uncontrolled land acquisition by grabbers enables them to exploit the land without any monitoring, leading to negative effects such as pollution, water depletion and habit loss to the environment. Therefore, stringent environmental and forest preservation laws through pollution monitoring and eco-friendly manners are to be respected in order to control farming and reduce degradation in Nguti.

\section{Conflicts of Interest}

The authors declare no conflicts of interest regarding the publication of this paper.

\section{References}

Aarts, V. (2009). Unveiling the Land Grab: How to Protect the Livelihoods of the Poor. 
Master Protect for AMID, 2009, CIDIN. Netherlands: Redmond University Nijmegen/ Oxfam Novib.

Friis, C., \& Reenberg, A. (2010). Land Grab in Africa: Emerging Land System Drivers in a Teleconnected World (pp. 1-46). GLP Report, No. 1, Copenhagen: GLP-IPO.

IIED (2009). Land Grabs in Africa: Can the Deals Work for Development? IIED, Briefing. https://www.iied.org/pubs/display.php 30/17069

International Labour Organisation (2009). Indigenous and Tribal Peoples Rights in practice. A Guide to ILO Convention No. 169 (pp. 8-56). International Labour Standards Department.

Julian, O. (2014). Our Land. Our Choice. The Great Land Heist. In Action Aid International (pp. 1-49).

Martin, A. (2007). Indigenous People and Protected Areas Management Parks in Peril. Innovations in Conserving Series (120 p).

Nguti Council (2008). Programme for the Sustainable Management of the Natural Resources (PSMNR), SWR, Nguti Council Monographic Study(306 p).

Nguti Council (2016). Forest Communities and Their Traditional Way of Life (210 p). Mapping and the Forest Governance Project, Cameroon.

Ngwa, C. I. (1997). Land Tenure Systems and Their Impact on Agro-Cultural Activities in Bafut Sub-Division (North West Cameroon) (125 p).

Schoneveld, G. C. (2013). The Governance of Large Scale Farmland Investments in SubSaharan Africa: A Comparative Analysis of the Challenges for Sustainability. The Netherlands: Eburon Publishers. https://doi.org/10.1016/j.foodpol.2014.03.007

Smaller, C., \& Mann, H. (2009). A Thirst for Distant Land. Foreign Investment in Agricultural Land and Water. International Institute for Sustainable Development, 48-59.

Tinyade, K. (2012). Land Grabbing in Africa: Review of the Impacts and the Possible Policy Responses (pp. 1-69).

United Nations (2010). The United Nations Declarations on the Rights of Indigenous People (pp. 11-66). A Manual for National Human Rights Institutions, 2010 Asia Pacific Forum, Office of the High Commission.

United Nations (2013). The United Nations Declarations on the Rights of Indigenous People (pp. 11-66). A Manual for National Human Rights Institutions, 2013 Asia Pacific Forum Office of the High Commission.

Von Brawn, J., \& Meinzen Dick, R. (2009). Land Grabbing by Foreign Investors in Developing Countries: Risks and Opportunities. IFPRI Policy Brief 13. Washington DC: International Food Policy Research Institute. 